\title{
Sinodalni pastoral mladih - iskustvo u Vrhbosanskoj nadbiskupiji
}

\author{
ŠIMO MARŠIĆ ${ }^{*}$ - ANTONIo TOPALOVIĆ** \\ - Marija PULJIĆ ${ }^{* * *}$ \\ • https://doi.org/ 10.31823/d.29.4.8 • \\ UDK: 272-73-053.6(497.6) • Pregledni članak \\ Primljeno: 18. siječnja 2021. • Prihvaćeno: 20. prosinca 2021.
}

* Izv. prof. dr. sc. Šimo

Maršić, Katolički bogoslovni fakultet,

Univerzitet u Sarajevu,

Josipa Stadlera 5,

71000 Sarajevo,

Bosna i Hercegovina,

marsicsimo@gmail. com

** Antonio Topalović, mag. paed.,

Nadbiskupijski centar za pastoral mladih

Ivan Pavao II., Gatačka

18, 71000 Sarajevo,

Bosna i Hercegovina, antonio_topalovic@ hotmail.com

*** Marija Puljić, mag. geogr., Nadbiskupijski centar za pastoral mladih Ivan Pavao II., Gatačka 18, 71000 Sarajevo,

Bosna i Hercegovina, marija.ncm@ gmail.com

Sažetak: Sinodalnost je kao stil pastoralnoga djelovanja u današnjem vremenu i shvaćanju Crkve značajna teološko-pastoralna tema. Ovdje ćemo je promatrati u kontekstu pastorala mladih i konkretno u kontekstu rada i djelovanja Nadbiskupijskoga centra za pastoral mladih Ivan Pavao II. u Sarajevu (dalje: NCM Ivan Pavao II.). Najprije ćemo se kratko zaustaviti na samom pojmu sinodalnoga pastorala te sinodalnoga pastorala mladih kao zahtjevu današnjega trenutka. Zatim ćemo predstaviti viziju i misiju NCM-a Ivan Pavao II. koji kroz instituciju Vijeća za mlade promiče sinodalnost, tj. uključenost mladih u proces suodlučivanja u pastoralu mladih. $\mathrm{Na}$ koncu ćemo se zaustaviti na trima različitim pastoralnim projektima NCM-a Ivan Pavao II. kroz koji sinodalnost u pastoralu mladih dolazi do izražaja, i to na trima razinama: formacija animatora župnoga pastorala mladih, socijalno zauzimanje mladih kroz volonterstvo te konkretno djelovanje mladih u medureligijskom i ekumenskom kontekstu.

Ključne riječi: Sinodalni pastoral, Nadbiskupijski centar za pastoral mladih Ivan Pavao II., Vijeće za mlade, pastoral mladih, animator, volonterstvo.

\section{Sinodalni pastoral mladih}

Riječ sinodalnost izvedenica je od grčke riječi syn-hodos, što znači 'ići zajedno, zajednički hod'. Drugi vatikanski koncil tu je osobinu ponovno otkrio ${ }^{1}$ kao nužan element crkve-

${ }^{1} \mathrm{O}$ povijesnom razvoju načela sinodalnosti u Crkvi kao načela zajedništva u: Ž. TANJIĆ, B. MURIĆ, Načelo sinodalnosti kao paradigma Crkve trećeg tisućljeća, u: Bogoslovska smotra 86(2016.)2, 275-295., ovdje 277-279. 
noga zajedništva (communio) i djelovanja te je osnovao ustanovu biskupske sinode. Riječ je, zapravo, o bitnoj dimenziji Crkve kao zajednice Božjega naroda koja sebe shvaća odrazom zajedništva u samom trojedinom Bogu. Stoga je Crkva nužno upućena na međusobno komuniciranje, osluškivanje, suradnju i suodlučivanje, razmjenu iskustava i darova između pastira i vjernika, različitih služba i redova u samoj sebi kako bi što bolje ostvarila svoju zadaću naviještanja i svjedočenja evanđelja.

U današnjoj evangelizaciji, kao zadaći svih vjernika, potrebna je stoga, u kontekstu navedenoga, zasigurno i promjena neprikladnih struktura i promjena mentaliteta. Razlog toj potrebi jest činjenica da je kod kršćanskih vjernika porasla razina opće naobrazbe, uključujući i teološku. Vjernici laici imaju izraženu svijest svojega ljudskoga dostojanstva, posjeduju različite kompetencije i na različite načine participiraju u društvenom životu. Isti ti vjernici, kao članovi crkvene zajednice, susreću se danas u Crkvi s potpuno drukčijim sustavom odnosa i vlasti, prema njima se odnosi kao prema pasivnim objektima pastoralnoga djelovanja. Drugi razlog potrebe promjene crkvenih struktura i mentaliteta jest koncilsko shvaćanje Crkve kao Božjega naroda kojega čine svi vjernici. Oni su dionici zajedničkoga svećeništva koje je temelj kršćanskoga poslanja. Takva slika Crkve zahtijeva međusobnu suradnju vjernika laika i hijerarhijskoga vodstva Crkve, zahtijeva, nadalje, suodgovornost i suodlučivanje na svim crkvenim razinama i vjernika laika. Sve to nalazi svoj izraz i sintezu u pojmu sinodalnosti kao stila pastoralnoga djelovanja. ${ }^{2}$

Papa Franjo u sedmom poglavlju apostolske pobudnice Christus vivit, govoreći o aktualnom trenutku pastorala mladih, naglašava potrebu sinodalnoga pastorala mladih u kojem bi sami mladi bili kreatori pastorala mladih. Potrebno je da se mlade ljude vodi, prati i da im se pomaže u njihovu kreiranju pastorala mladih, ali u isto vrijeme da im se dopusti sloboda razvijanja novih pristupa svojom kreativnošću i odvažnošću. $\gg$ Pastoral mladih jednostavno mora biti sinodalan, to jest sposoban oblikovati jedan 'zajednički hod' koji podrazumijeva 'vrednovanje darova koje Duh daje u skladu s pozivom i ulogom svakog pojedinog člana (Crkve), kroz dinamizam suodgovornosti. $\ll^{3}$

\section{Nadbiskupijski centar za pastoral mladih Ivan Pavao II.}

Papa Ivan Pavao II. u svojoj je propovijedi u Banjoj Luci 22. lipnja 2003. godine pri proglašenju blaženim Ivana Merza poručio mladima u $\mathrm{BiH}$ : »Vaša domovina i vaša Crkva, draga mladeži, doživjele su teške trenutke i sada valja raditi kako bi se život ponovno u potpunosti pokrenuo na svim područjima. Obraćam se zato svima

${ }^{2}$ Usp. N. ANČIĆ, Prema sinodalnoj Crkvi, u: Bogoslovska smotra 86(2016.)2, 267-271., ovdje 268.

${ }^{3}$ Usp. FRANJO, Christus vivit - Krist živi. Postsinodalna apostolska pobudnica Svetoga oca Franje mladima i cijelom Božjem narodu, Zagreb, 2019., 204-206. (= ChV). 
vama te vas pozivam da se ne povlačite nazad, da ne popuštate pred napašću malodušnosti, nego da povećate pothvate kako bi Bosna i Hercegovina ponovno postala zemlja pomirbe, susreta i mira. Budućnost ovih krajeva ovisi i o vama. Ne tražite drugdje udobniji život, ne bježite od svoje odgovornosti čekajući da vam netko drugi riješi teškoće, nego zlo odlučno priječite snagom dobra. I vi poput blaženog Ivana tražite osobni susret s Kristom, koji rasvjetljuje život novom svjetlošću. Neka Evanđelje bude ono veliko mjerilo, koje će ravnati vašim sklonostima i vašim opredjeljenjima! Postat ćete tako misionari djelima i riječima te ćete biti znak Božje ljubavi, vjerodostojni svjedoci milosrdne Kristove nazočnosti. Ne zaboravite: 'Ne užiže se svjetiljka da se stavi pod posudu' (Mt 5,15). $\ll^{4}$ Te Papine riječi i podrška i ohrabrenje nadbiskupa Vinka Puljića bile su poticaj Povjerenstvu za mlade da od početka svojega rada 2004. godine uključi aktivno mlade u pastoral mladih. Tako se mladi najprije volonterski uključuju u rad Povjerenstva (organizacija susreta Tabor, Dan mladih u Komušini, animiranje svetih misa), onda i honorarno (organizacija hodočašća mladih iz Vrhbosanske nadbiskupije na Svjetski dan mladih u Köln, uređivanje Glasa mladih u Katolickom tjedniku), a od 2007. godine, nakon osnivanja Nadbiskupijskoga centra za pastoral mladih Ivan Pavao II., i kao koordinatori projekata za mlade (Škola animatora župnog pastorala mladih).

Bio je logičan slijed i korak dalje u strukturiranju pastorala mladih na nadbiskupijskoj razini osnivanje jedne institucije unutar Katoličke Crkve Vrhbosanske nadbiskupije koja će biti konkretan znak zauzetosti Crkve za pastoral mladih, a po primjeru organiziranosti i strukturama Katoličke Crkve u zemljama zapadne demokracije. Odlukom o osnivanju te institucije 2007. godine određuje se i temeljna zadaća iste, a koja se ogleda u promoviranju i koordiniranju pastorala mladih i sveučilištaraca na nadbiskupijskoj razini, kreiranju i ponudi suradnje župama u traženju novih odgojnih projekata kršćanske formacije mladih, promoviranju međusobnoga poznavanja i suradnje različitih udruga, pokreta i skupina mladih aktivnih na području nadbiskupije te suradnji s drugim organizacijama, društvima u zemlji i inozemstvu. ${ }^{5}$

Nova institucija Katoličke Crkve unutar Vrhbosanske nadbiskupije dobiva od svojega osnivača 13. lipnja 2014. godine pod brojem 1052/2014 i Statut kojim se dodatno regulira rad Nadbiskupijskoga centra za pastoral mladih Ivan Pavao II. ${ }^{6}$ Sta-

\footnotetext{
${ }^{4}$ Usp. KATOLIČKA TISKOVNA AGENCIJA, Papina propovijed na misi u Banjoj Luci. Dostupno na: http://www.ktabkbih.net/info.asp?id=5979 (25. 3. 2020.).

${ }^{5}$ Usp. Š. MARŠIĆ, Kardinal Vinko Puljić i Nadbiskupijski centar za pastoral mladih »Ivan Pavao II.«, u: S. ĆOSIĆ, P. JURIŠIĆ, M. KALFIĆ, D. TOMAŠEVIĆ (ur.), Vrhbosanska mjesna Crkva i njezin kardinal. Zbornik radova povodom 75. godine života, 50. obljetnice svećeničke službe, 30. obljetnice biskupske službe i 25. obljetnice kardinalske službe Vinka Puljića, Sarajevo 2020., 268.
}

${ }^{6}$ Statut Nadbiskupijskog centra za pastoral mladih »Ivan Pavao II.«, u: Vrhobosna 128(2014.)2, 104108. 
tutom se kao »općim aktom NCM Ivan Pavao II. utvrđuje i uređuje status NCM Ivan Pavao II., njegov naziv, sjedište i pečat, djelatnost, upravljanje, rukovođenje i kontrola poslovanja, te druga pitanja značajna za rad i poslovanje « (čl. 2). S obzirom na ciljeve i djelatnost Statut NCM-a Ivan Pavao II. jasno u članku broj 8 kaže da je ta ustanova osnovana $\mathrm{u} \gg$ cilju odgoja, rasta u vjeri, susreta s drugima i drugačijima i mogućnošću dodatnog obrazovanja mladih «, a sve radi obavljanja pastoralne djelatnosti usmjerene prema mladima (čl. 1).

Misija NCM-a Ivan Pavao II. ogleda se kroz tri okosnice djelovanja: duhovnost, susreti i izobrazba, a one se ostvaraju pomoću kvalitetnoga programa osmišljenoga prema potrebama mladih. Kroz neformalno obrazovanje, duhovne, kreativne, zabavne, edukativne i sportske susrete, zahvaljujući Božjoj providnosti, ali i potpori prijatelja i donatora, mladi iz osnovnih i srednjih škola te studenti imaju priliku sudjelovati na projektima koji jačaju duhovnost, promoviraju volonterstvo i aktivizam mladih. U sklopu projektnih aktivnosti mladi također rade i na prevenciji različitih vrsta ovisnosti, razvijaju međureligijski dijalog, demokraciju, zaštitu i očuvanje ekologije, zaštitu djece i njihovih prava, brigu o marginaliziranim skupinama mladih i sl.

Možemo reći da se u samom imenu zapravo nalazi i vizija i misija NCM-a Ivan Pavao II. Sveti Ivan Pavao II. gradio je naime mostove prema ljudima različitoga podrijetla i različitih uvjerenja, a mostovi su smjernice za stanje u $\mathrm{BiH}$, ali i u Europi. Ivan Pavao II. imao je poseban odnos prema mladima, volio ih je i imao je povjerenje u njih, a i oni su bili oduševljeni susretom s njim. Stoga je i dugoročni cilj NCM-a Ivan Pavao II. biti žarište različitih inicijativa u pastoralu mladih, osluškujući mlade, pružajući im prostor rasta u vjeri i razvoju vlastitih sposobnosti, upoznavanju drugih i drukčijih i preuzimajući aktivnu ulogu u pastoralu.

Godišnje se u NCM-u Ivan Pavao II. realizira oko 40-ak projekata kroz koje prođe oko 10000 mladih iz cijele Vrhbosanske nadbiskupije, ali i šire. Tim bogatstvom projekata i njihovim specifičnim ciljevima Crkva izražava svoju otvorenost i povjerenje u mlade na njihovu putu odrastanja i ohrabruje ih da se aktivno uključe u život Crkve i društva doprinoseći boljitku i napretku.

NCM Ivan Pavao II. mjesto je koje mladima pomaže u njihovu rastu i razvoju na način da preuzimanjem zadataka i sudjelovanjem u njima preuzimaju odgovornost, susreću se s drugima, umrežavaju i kristaliziraju svoju poziciju i viziju u Crkvi i društvu. Mladi kroz zajedničke projekte stječu iskustvo da sa svojim snovima, strahovima, brigama, željama i vizijama nisu sami. Ta vrijedna zajednička iskustva daju im snagu i priliku da pokažu javnosti da je mladež miroljubiva i društveno odgovorna jer zajedničkim snagama mladi ljudi nadilaze predrasude o različitim vjerskim i nacionalnim pripadnostima, razvijaju prijateljstva, podupiru izmirenje i mir 
u zemlji, za zemlju i zajednicu u kojoj se razlike rijetko shvaćaju kao kvalitete i šanse, što je jedan od temelja za razvoj građanina 21 . stoljeća, a predstavlja imperativ razvoja i održivosti cijeloga društva. ${ }^{7}$ Aktivno djelovanje u Crkvi i pastoral mladih koji mlade promatra kao nositelje samih aktivnosti zahtijeva njihovo pravodobno uključivanje i kontinuitet njihova angažmana. $S$ druge strane Crkva i društvo trebaju kreirati okruženje u kojem će se mladi osjećati poželjno i dobrodošlo, što treba biti i vidljivo. ${ }^{8}$

\section{ViJeĆE ZA MLADE VRHBOSANSKE NADBISKUPIJE}

Kako bi učinili da sinodalni pastoral mladih ima i svoju strukturu, NCM Ivan Pavao II. početkom 2009. godine pokreće inicijativu za osnivanje Vijeća za mlade kao reprezentativnoga, savjetodavnoga i djelatnoga tijela koje proučava, planira, usklađuje, priprema i provjerava izvođenje pastorala mladih na razini nadbiskupije. ${ }^{9} \mathrm{Vi}$ jeće za mlade Vrhbosanske nadbiskupije čine mladi predstavnici dekanata i udruga mladih s područja nadbiskupije. Predsjednik Vijeća jest nadbiskup, a tajnik Vijeća jest povjerenik za pastoral mladih Vrhbosanske nadbiskupije (ravnatelj NCM-a Ivan Pavao II.). Konstituirajuća sjednica Vijeća održana je 26. lipnja 2009. godine. ${ }^{10}$ Vijeće za mlade Vrhbosanske nadbiskupije osnovano je $\gg$ radi ostvarivanja zajedničkih interesa na oblikovanju i provedbi zajedničke politike za mlade na razini Nadbiskupije, te radi poboljšanja kvalitete i uvjeta života mladih, te jačanja njihove samosvijesti za aktivno i odgovorno sudjelovanje u životu kako župne zajednice tako i mjesne Crkve $\ll^{11}$

\section{Mladi za mlade - Formacija animatora}

Mladi za mlade - vizija je toga pastoralnoga projekta da se na župnim razinama formiraju animatori koji će rasti i sazrijevati u vjeri te odgovorno i organizirano $u$ suradnji sa župnikom ili kapelanom sudjelovati u životu župe, a osobito u pastoralu djece i mladih.

Mladi danas od društva i Crkve traže mnogo toga, što je, dakako, sasvim u redu i poželjno. No društvo i Crkva često nisu u mogućnosti ponuditi ono što mladima

\footnotetext{
${ }^{7}$ Usp. C. ROCHESTER, Volunteering and Society in the 21st Century, New York, 2010.

${ }^{8}$ Usp. J. KÜPPER, K. W. HEMPFER, E. FISCHER-LICHTE (ur.), Religion and Society in the 21st Century, Berlin - Boston, 2014., 145.

${ }^{9}$ Statut Vijeća za mlade Vrhbosanske nadbiskupije, čl. 1., u: Vrhbosna 128(2009.)4, 367-371.

${ }^{10}$ Usp. NADBISKUPIJSKI CENTAR ZA PASTORAL MLADIH $\gg$ IVAN PAVAO II. «, Malim koracima 2009. Kronologija nadbiskupijskog centra za pastoral mladih »Ivan Pavao II.«, Sarajevo, 2010., 20-25.

${ }^{11}$ Statut Vijeća za mlade Vrhbosanske nadbiskupije, čl. 2.
} 
treba. Nekada to ne znaju, a nekada jednostavno ne smatraju važnim ono što mladi od njih traže. ${ }^{12} \mathrm{U}$ pastoralnoj praksi ponekad se dobiva dojam da se Crkva i mladi ne razumiju najbolje, da hodaju u dvama različitim smjerovima koji su temeljeni na različitim vrijednostima. ${ }^{13}$ Crkva mlade smatra svojim pastoralnim prioritetom te je tu brigu iskazivala na različite načine: kroz dokumente, konkretne geste i druge odgojno-pastoralne projekte. Ivan Pavao II. u dokumentu Christifideles laici govori o razlozima osobite crkvene pozornosti prema mladima te ističe: $\gg U$ mladima Crkva čita svoj hod prema budućnosti.« Također ističe da su mladi aktivni nosioci evangelizacije i začetnici društveno-crkvene obnove. ${ }^{14} \mathrm{Na}$ mlade se danas gleda kao na važne članove crkvene zajednice i od njih se zahtijeva posebna odgovornost, Crkva računa na apostolat mladih. Oni bi trebali biti prvi i izravni apostoli drugim mladima, nosioci radosne poruke od srca do srca poštujući zakonitosti vremena i sredine u kojoj se nalaze. Poštujući takva načela, crkvene institucije pokušavaju svakodnevno kreirati i provoditi projekte u kojima su mladi aktivni nosioci samih aktivnosti te tako postaju evangelizatori, s jakim vrijednosnim utemeljenjem i konačnom svrhom.

Upravo od takve postavke polazi projekt Mladi za mlade koji se već 15 godina organizira i realizira u Vrhbosanskoj nadbiskupiji ${ }^{15}$, a njegova se vizija očituje u tome da se na župnim razinama formiraju animatori mladih koji će rasti i sazrijevati u vjeri te odgovorno i organizirano u suradnji sa župnikom ili kapelanom sudjelovati u životu župe, a osobito u pastoralu djece i mladih. Projektom se također želi pomoći mladima u cjelovitom razvoju te osnažiti njihove liderske vještine, kako bi preuzeli ulogu inicijatora, najprije u svojoj župnoj zajednici, a zatim i na dekanatskoj i nadbiskupijskoj razini. Projekt je nastao kao odgovor na izazove s kojima se mladi danas susreću, a to je besperspektivnost koja je nastala u zemlji kao plod različitih društvenih, ekonomskih i političkih čimbenika.

Prvi pokušaj teorijske postavke i praktičnoga usmjerenja animatorstva i animatora sadržan je u Dosjeu Društva Kćeri Marije Pomoćnice (1982.) te u dokumentu Salezijanski prijedlog udruživanja - Sinteza jednog iskustva i hoda (1985.). U njima je skupljena praksa koja se razvijala u različitim kontekstima, a svodi se na zaključak: skupine i pokrete koji nastaju u Crkvi, osim maksimalne otvorenosti i odgojnoga značenja, obilježava oblik odnosa, način izrade sadržaja i stil praćenja koji se izra-

${ }^{12}$ Usp. M. THUMMALAPALLI, The Role of a Lay Youth Animator in Forming the Young, Saarbrücken, 2018., 48.

${ }^{13}$ Usp. M. OFFI, F. GARELLI, Giovani. Una vechia storia?, Torino, 1997., 25.

${ }^{14}$ Usp. V. MANDARIĆ, Mladi - integrirani ili marginalizirani, Zagreb, 2009., 234.

${ }^{15}$ Usp. Š. MARŠIĆ, Kardinal Vinko Puljić i Nadbiskupijski centar za pastoral mladih »Ivan Pavao II. $\ll, 266$. 
žavaju riječju animiranje. ${ }^{16}$ Takav vid prakse nije rijetkost u suvremenoj pastoralnoj praksi, a obuke i edukacije koje se nude za mlade animatore svakako su postale ustaljena aktivnost koja ima vidljive rezultate u samom djelovanju unutar župa i župnih ili biskupskih zajednica, pokreta i laičkih udruženja. ${ }^{17}$ Prisutnost animatora $\mathrm{u}$ zajednici očituje se u tome da se on osjeća korisnim članom te iste zajednice $\mathrm{i}$ odlučuje se za aktivno participiranje u pastoralnom životu Crkve, on u njoj želi rasti nastojeći ujedno pomoći zajednici da i ona raste i unaprjeđuje svoj apostolat. Animator svojom aktivnošću ponajprije izgrađuje i jača svoje snage kao građanina i kršćanina, ali s druge strane u suradnji i suodnosu s mladima nastoji pružiti i drugima to isto ili slično iskustvo.

NCM Ivan Pavao II. već niz godina prepoznaje župne zajednice mladih kao izvrstan prostor za djelovanje te mladi animatori, koji prolaze jednogodišnju obuku, usvajaju različita znanja, vještine i kompetencije koje im pomažu u radu s vršnjacima. Važno je znati da animatori ne mogu (i ne trebaju) biti sami na putu svoga djelovanja u župama ili biskupiji. Njima je potrebna trajna podrška, usmjeravanje i mentorstvo svećenika, časnih sestara, kateheta ili osoba zaduženih za mlade u župama. Upravo iz zajedničkoga, suradničkoga odnosa između mladih i odraslih, između mladih koji dolaze iz različitih društvenih okolnosti i Crkve koja nastoji djelovati iz svoje perspektive, rađa se pastoral mladih. Važno je napomenuti da animatori u susret $\mathrm{s}$ drugim mladima nose sebe i svoje izazove i poteškoće $\mathrm{s}$ kojima se svakodnevno susreću te je na taj način sama uloga svećenika važnija i značajnija, a istraživanje iz 2013. godine, provedeno u Bosni i Hercegovini, naglašava da mladi upravo od svećenika očekuju duhovnu pomoć i podršku $(65,6 \%)$ te da je ona ključna u njihovoj motivaciji i poticaju za daljnje djelovanje. ${ }^{18}$ Kada promišljamo o globalnom odnosu prema pastoralu mladih u Europi i svijetu, primjećujemo identičnu potrebu mladih, a ona je ponajprije povezana s podrškom Crkve i njezinih službenika u rastu i razvoju, dok angažirani mladi (animatori, volonteri, ministranti...) naglašavaju da je podrška katehete i/ili svećenika neizostavna za uspješan projekt ili aktivnost u župi. ${ }^{19}$

Iz iskustva Vrhbosanske nadbiskupije, sa sigurnošću možemo tvrditi da je mladima u Crkvi potreban prostor, ali i sloboda kako bi taj prostor iskoristili na najbolji

\footnotetext{
${ }^{16}$ Usp. E. MAIOLI, J. VECCHI, Animator u skupini mladih, Zagreb, 1999.

${ }^{17}$ Usp. Š. MARŠIĆ, Mladi Vrhbosanske nadbiskupije u godini vjere. Laički pokreti u službi nove evangelizacije, Sarajevo, 2013., 18.

${ }^{18}$ Usp. isto, 36.

${ }^{19}$ Usp. H. SALOMÄKI, The Future of Youth Work in the Dioceses of Lapua and Oulu: Youth Workers' Views on Professional Identity, Training Needs, Regional Issues and Work Prospects, Kokkola, 2004., 187.
} 
način i od njega učinili nešto veliko. Prvi koraci djelovanja unutar župne zajednice kod većine mladih izravno se vežu uz formaciju animatora Mladi za mlade, čemu svjedoče brojna iskustva i priče mladih koji se kontinuirano prikupljaju. Uz usvajanje svih vještina i kompetencija, bogatstvo upoznavanja mladih iz cijele države za mlade ima veliko značenje. NCM Ivan Pavao II. nudi osnovne alate s pomoću kojih se mogu učiniti promjene u zajednicama, ali svakako nastoji biti i trajna podrška svim mladima u realizaciji njihovih aktivnosti. $U$ dugogodišnjem radu s mladima neizostavno je uočiti potrebu za trajnom edukacijom i supervizijom u njihovu radu, odnosno animatori se reflektivno trebaju vraćati na ono što čine te u skladu $s$ tim popraviti ono što nije bilo funkcionalno, a zadržati i unaprijediti ono što je dobro, što ne mogu sami. U svakodnevnom jeziku supervizija znači nadgledanje s konotacijom autoriteta, upravljanja i rukovođenja. ${ }^{20} \mathrm{U}$ pastoralu mladih supervizija se razumijeva kao trajna podrška ispunjena smjernicama i uputama za daljnje djelovanje, a osvrćući se na iskustvo onih koji realiziraju određenu aktivnosti. ${ }^{21}$

Djelatnici NCM-a Ivan Pavao II. primjećuju da se današnje društvo uvelike razlikuje od onoga na što smo se naviknuli, a izazovi s kojima se mladi suočavaju veći su iz dana u dan. Nužno je motivirati, pokrenuti proaktivnu energiju kod mladih, učiniti ih aktivnim kreatorima, i svoje budućnosti i budućnosti cijele zajednice. Motivirati mladu osobu nije lako, ali je dragocjeno. U skladu s tim nužno je upoznati što današnje mlade mori, koji su problemi s kojima se susreću, što ih sprječava da slobodno žive svoju svakodnevnicu. To nije jednostavno, ima svoju dinamiku i društveno je uvjetovano. Političke, ekonomske, javnozdravstvene i druge prilike uvjetuju ponašanje mladih. Često ih je strah budućnosti, ponekad se osjećaju besperspektivno i pesimistično, ali su spremni učiniti nešto sa svojim životom.

Naposljetku, program Mladi za mlade iz godine u godinu prepoznaje se kao kvalitetan i efikasan te doživljava veliku podršku župnika iz svih biskupija u Bosni i Hercegovini. Također je važno naglasiti osobna iskustva mladih koji su bili članovi projekta, a koji su nakon završetka temeljne formacije ostali aktivni i u župama i pri NCM-u Ivan Pavao II. Danas program Mladi za mlade godišnje broji 70 mladih koji prolaze kroz temeljne formacije, što svakako nije malen broj, a oni svjedoče živu Crkvu, proaktivno djelovanje i radost mladosti. Uz temeljne formacije, animatori su nositelji i niza drugih aktivnosti kao što su ljetni programi pod nazivom Dječja ljeta, susreti krizmanika i prvopričesnika, sustavni rad s ministrantima, ali i niz drugih aktivnosti u kojima je vidljiva uloga i poslanje župnoga animatora mladih.

\footnotetext{
${ }^{20}$ Usp. M. AJDUKOVIĆ, Ž. POTOČKI, B. SLADOVIĆ. Supervizija u Hrvatskoj: preliminarno ispitivanje stavova i očekivanja socijalnih radnika, u: Ljetopis socijalnog rada 6(1999.) 1, 30.

${ }^{21}$ Usp P. VANKATWYK. Spiritual Care and Therapy: Integrative Perspectives, Ontario, 2003., 157.
} 
Unastavku Vam donosimo iskustvo jednoga polaznika Škole animatora u 2019./2020. godini.

»Protekle formacije i specijalizacija su nešto najljepše što mi je Bog dao. Upoznao sam nove ljude, koji su ovdje došli iz različitih dijelova $\mathrm{BiH}$. Što je najvažnije, sklopio mnoga nova prijateljstva. To je jedno prekrasno iskustvo koje se može doživjeti. Svi su raspoloženi, družimo se i postajemo jedna prava obitelj. Naravno tu su i naši animatori instruktori, divni ljudi koji daju $200 \%$ od sebe, da bi nas nešto naučili. Kroz razne prezentacije, radionice, plesove i igre učimo o animatorskom pozivu, radu s djecom, ali najvažnije, učimo biti pošteni ljudi i kako živjeti u vjeri. Drago mi je što sam odabran da doživim ovu prekrasnu pustolovinu punu veselja, smjeha i zabave.«

Vjekoslav Majksner, Mostar

\section{4. Škola volonterstva - 72 sata bez kompromisa}

Crkva, kao mjesto podrške cjelovitom razvoju mlade osobe, treba biti i ona koja će ih poticati da iziđu iz vlastite zone komfora. Treba biti poticaj mladima da sazrijevaju u vjeri koja teži otvorenosti drugima, a to podrazumijeva ići ususret onima koji su na rubu društva i onima koji su drukčiji s obzirom na vjersku pozadinu. Upravo iz toga razloga NCM Ivan Pavao II., uz osnovno poslanje, a to je da pruži priliku mladima za rast u katoličkoj vjeri i usavršavanje vlastitih vještina i talenata, svojim programima potiče ih i da volontirajući budu tu za one koji su u potrebi u župnim zajednicama te da budu promotori mira i pomirenja u svojoj zemlji. Volonterstvo se ne sastoji samo u konkretnoj akciji, već i u odluci da pojedinac ili skupina ostavi trag na živote drugih ljudi s jasnom intencijom djelovanja, opredijeljenošću za dobro čovjeka i održivost zajednice kao mjesta življenja. ${ }^{22}$

Škola volonterstva jest projekt koji NCM Ivan Pavao II. realizira radi uključivanja mladih u konkretne volonterske zadatke u svojim lokalnim zajednicama, kako bi živjeli kršćansku solidarnost i svojim primjerom vršnjacima pokazali odgovornost u društvu. Papa Franjo u svojoj apostolskoj pobudnici Christus vivit poziva mlade da budu protagonisti promjene, da pobijede bezvoljnost i uključe se aktivno i s punim entuzijazmom u izgradnju boljega društva. ${ }^{23}$ Kardinal Vinko Puljić na sjednici Vijeća za mlade Vrhbosanske nadbiskupije 2. listopada 2009. godine prihvaća ideju pokretanja volonterske akcije mladih 72 sata bez kompromisa na području Vrhbo-

\footnotetext{
${ }^{22}$ Usp. C. ROCHESTER, Volunteering and Society in the 21st Century, New York, 2010., 67.

${ }^{23}$ Usp. ChV, br. 170.
} 
sanske nadbiskupije, a cilj je projekta razvijanje svijesti kod mladih ljudi o važnosti volontiranja utemeljenoga na kršćanskoj solidarnosti. ${ }^{24}$

Taj projekt ponudio je priliku brojnim mladima u školskim i župnim zajednicama da najprije uče o kršćanskom volonterstvu i njegovoj važnosti te mogućnostima kvalitetnoga provođenja vremena, a zatim da to praktičnim radom pokažu. Kako se u medijima općenito mnogo više pozornosti posvećuje lošim vijestima, NCM Ivan Pavao II. prepoznao je potrebu da mlade educira i o važnosti širenja pozitivnih priča kako bi one donosile nadu, svježinu i bile motivacija drugima. Iz toga razloga od 2018. godine u projekt je kao suradnik uključen Medijski centar Vrhbosanske nadbiskupije te se krenulo i s radionicama o medijskoj pismenosti i prepoznavanju medijskoga prostora kao izvrsnoga promotora dobrih priča i cjelovitoga informiranja. Na taj način proširena je mreža aktera koji sudjeluju u pastoralu mladih te se još više mlade potaknulo da budu kreatori novih ideja, da jačaju svijest o volonterstvu, prožetom medijskim aktivizmom.

U 2019. godini realizirano je 37 malih volonterskih i medijskih akcija, u koje je bilo uključeno oko 1000 mladih i 40-ak njihovih voditelja, što svakako ide u prilog ozbiljnosti toga projekta. ${ }^{25} \mathrm{U}$ volonterskim akcijama mladi se nisu libili zasukati rukave i raditi fizičke poslove: čistili su, renovirali, pokazivali su kreativnost pri uređenju prostora i dvorišta, poklanjali su svoje vrijeme onima koji su zaboravljeni i marginalizirani, zaboravljenim mjestima i prostoru vraćali su stari sjaj.

Usko vezana uz Školu volonterstva jest i velika, ranije spomenuta, volonterska akcija 72 sata bez kompromisa. Prije 10 godina, sredinom listopada, 800 volontera iz cijele Bosne i Hercegovine nije ni slutilo da će svojim prvim volonterskim koracima postati dio uspješne volonterske priče Vrhbosanske nadbiskupije. Podijeljeni u skupine, te davne 2010. godine njih 500 odlučilo je tijekom tri dana darovati sebe potrebitima u 19 župa i organizacija volontirajući na 37 projekata, koliko ih je te godine bilo osmišljeno. ${ }^{26}$ Cilj je te akcije okupiti mlade koji su spremni odvojiti svoje slobodne vrijeme te beskompromisno pomoći osobama u potrebi radeći na socijalnim, kreativnim, karitativnim, ekološkim, duhovnim projektima u svojoj župnoj zajednici. Akcija se održava svake druge godine te se zaključno s 2020. godinom održala posljednja, šesta akcija 72 sata bez kompromisa.

${ }^{24}$ Usp. Š. MARŠIĆ, Kardinal Vinko Puljić i Nadbiskupijski centar za pastoral mladih »Ivan Pavao II. $\ll, 284$.

${ }^{25}$ Usp. NADBISKUPIJSKI CENTAR ZA PASTORAL MLADIH »IVAN PAVAO II.«, Kronologija projekta Škola volonterizma, Sarajevo, 2019., 10.

${ }^{26}$ Usp. NADBISKUPIJSKI CENTAR ZA PASTORAL MLADIH »IVAN PAVAO II.«, Projektna dokumentacija 6. volonterske akcije 72 sata bez kompromisa, Sarajevo, 2020., 5. 


\section{Koračajmo zajedno - međureligijski projekt za mlade}

U svemu što rade mladi trebaju biti oni koji grade poštovanje prema svim ljudima, imajući na umu dostojanstvo svake osobe. Koncept ljudskoga dostojanstva obuhvaća ono što obrazovanje o etici nastoji promovirati u njegovanju vrijednosti i etičkih načela. Čovječnost jedne osobe zanijekana je kada je njezino dostojanstvo zgaženo. $^{27}$

Mladi na poseban način trebaju biti ti koji su spremni obogatiti jedni druge onim što jesu i u što vjeruju. Iz toga razloga predstavljaju važne aktere u promicanju međureligijskoga dijaloga, mira i pomirenja, koji su temelji zdravoga suživota. ${ }^{28}$ Upravo zato nastao je projekt Koračajmo zajedno koji želi biti odgovor, u podijeljenom društvu, na potrebe mladih da se lanac prošlosti kojim je ovijena Bosna i Hercegovina konačno slomi. Primjećujemo da mladi gube povjerenje u političke institucije, ali da isto još uvijek gaje prema religijskim institucijama, koje na to trebaju odgovoriti iskrenim poticajem mladima da vjeruju da je dijalog moguć. Podrška vjerskih poglavara upravo je temelj za realizaciju projektnih aktivnosti. Stoga od 2013. godine NCM Ivan Pavao II. realizira međureligijski i ekumenski projekt Koračajmo zajedno, u suradnji s Pravoslavnim centrom za mlade Mitropolije dabrobosanske Sveti Petar Sarajevski te od 2017. godine u suradnji is Fakultetom islamskih nauka u Sarajevu. ${ }^{29}$

Cilj je projekta potaknuti mlade triju većinskih vjeroispovijesti u $\mathrm{BiH}$ da razvijaju osjećaj odgovornosti prema vlastitoj zemlji i otkrivaju bogatstvo različitosti unutar nje, nadilaženjem predrasuda i međusobnim upoznavanjem, kako bi zajedno doprinijeli izgradnji kulture mira i bolje budućnosti. Projekt nikako ne podrazumijeva sinkretizam, ali podrazumijevaju vjerski pluralizam - dijalog na temelju raznolikosti i podršku mladima da se bore za bolju sadašnjost u vlastitoj zemlji.

Projektom se želi pružiti prilika mladima različitih etničkih pripadnosti, a posebno onima koji dolaze iz jednonacionalnih sredina, da sretnu svoje vršnjake iz različitih mjesta te da se upoznaju s bogatstvima svoje zemlje. Nadilazeći predrasude prema mladima drugih vjeroispovijesti, projektom se daje mogućnost mladima da stvaraju okruženja u kojima se grade nova prijateljstva bez stigmatizacije i gdje mladi iz vlastitih svjetonazora crpe snagu za mir sa svojim bližnjima, a time doprinose i

\footnotetext{
${ }^{27}$ Usp. MEĐURELIGIJSKO VIJEĆE ZA OBRAZOVANJE DJECE U ETICI, SVJETSKA MREŽA RELIGIJA ZA DJECU, FONDACIJA ARIGATOU, Učiti živjeti zajedno: Interkulturalni i medureligijski program za obrazovanje o etici, Ženeva, 2008., 8.

${ }^{28}$ Usp. H. RAUTIONMAA, Religious Dialogue: Education to Encounter Cultures, Helsinki, 2010., 17.

${ }^{29}$ Usp. NADBISKUPIJSKI CENTAR ZA PASTORAL MLADIH »IVAN PAVAO II.«, Kronologija Nadbiskupijskog centra za pastoral mladih »Ivan Pavao II.« - Malim koracima 2017./2018., Sarajevo, 2018., 43.
} 
miru u cijeloj zemlji. Stoga se tim projektom također želi pružiti model suživota drugim mladim ljudima i dokazati im da je moguće voljeti svoju tradiciju i živjeti svoju vjeru, istodobno poštujući drugoga i surađujući s njim.

Pri uključivanju mladih u proces izgradnje mira vodi se računa o tome da se uvijek govori jezikom koji mladi razumiju, odnosno da im se ponude aktivnosti koje vole. Aktivnosti koje se mladima nude trebaju se dijelom planirati na osnovi potreba i želja samih mladih, a dijelom na osnovi potreba zajednice i vrijednosti kojima mladi pripadaju. Osnova za razumijevanje i kreiranje socijalnoga konteksta odgoja i obrazovanja temelji se na suodnosu između potreba i želja, njihovoj sintezi i djelovanju s intencijom općega i individualnoga dobra. ${ }^{30}$ Stoga je nekoliko okosnica na kojima se projekt temelji:

- Mogućnost susreta i učenja kroz interaktivne vježbe i zajednička putovanja - Kroz realizaciju tematskih radionica u školama i župama, pod vodstvom vršnjačkih edukatora - studenata različitih fakulteta u Sarajevu, mladi imaju priliku učiti o važnosti nadilaženja predrasuda, upoznavati vjerske običaje u Bosni i Hercegovini iz perspektive vršnjaka drugih vjerskih pozadina te učvršćivati se $\mathrm{u}$ vlastitom identitetu, kulturi i zajedničkim vrijednostima. Za mlade je također važan posjet vjerskim objektima, susret $s$ lokalnim vjerskim službenicima te studijska putovanja koja uključuju učenike različitih škola radi upoznavanja prirodnih i kulturnih vrijednosti Bosne i Hercegovine.

- Sport kao prilika zdravoga odgoja mladih - Papa Franjo u predgovoru dokumenta Dati najbolje od sebe $e^{31}$ ističe sport kao povlašteni prostor oko kojega se ljudi susreću bez ikakve razlike u rasi, spolu, religiji ili ideologiji te gdje mladi mogu doživjeti radost zajedničkoga natjecanja radi postizanja zajedničkoga cilja. Papa također naglašava snažnu poruku sporta, a to je da se do cilja ne može doći usredotočujući se isključivo na samoga sebe, nego da je $\gg$ velika momčad uvijek sastavljena od velikih pojedinaca, koji ne igraju sami već zajedno «. Iz toga razloga unutar projekta organiziraju se međureligijski sportski susreti u lokalnim zajednicama, kao i Utrka za mir u Sarajevu, u povodu Međunarodnoga dana mira.

- $\gg$ Gradite mostove, a ne zidove $\ll$ - Pri posjetu Sarajevu i NCM-u Ivan Pavao II., u lipnju 2015. godine, papa Franjo izrekao je rečenicu: $\gg$ Gradite mostove, a ne zidove $\ll^{32}$, koja je na poseban način potaknula djelatnike NCM-a Ivan Pavao

${ }^{30}$ Usp. R. WHITE, J. WYN, Youth and Society. Exploring the Social Dynamics of Youth Experience, u: Tidsskrift for Ungdomsforskning 5(2014.)2.

${ }^{31}$ Usp. DIKASTERIJ ZA LAIKE, OBITELJ I ŽIVOT, Dati najbolje od sebe: O kršćanskom pogledu na sport i osobu, Zagreb, 2019.

32 https://www.ktabkbih.net/hr/izdvajamo/govor-svetoga-oca-na-susretu-s-mladima-u-saraje$\mathrm{vu} / 57043$ (7.3. 2021.). 
II. da i dalje, u suradnji s partnerima, brojnim aktivnostima nastoje biti oslonac mladima u prepoznavanju uloge $\mathrm{u}$ bosanskohercegovačkom društvu te otkrivanju vlastite snage u kreiranju kvalitetnijega ozračja u Bosni i Hercegovini. Stoga se već dvije godine organizira međureligijski kamp za mlade, koji okuplja 50 mladih triju većinskih vjeroispovijesti u Bosni i Hercegovini. Kroz sedmodnevni kamp mladi imaju priliku učiti o prirodnim i kulturnim potencijalima Bosne i Hercegovine, kao zajedničkom bogatstvu, posjetiti i upoznati vjerske objekte, posjetiti prirodne i kulturne znamenitosti te sudjelovati u zabavno-rekreativnim aktivnostima.

Važnost toga projekta za mlade u Bosni i Hercegovini najbolje potvrđuju njihova iskustva pretočena u riječi:

$\gg$ Kao koordinator Mreže mladih Medžlisa islamske zajednice u Zenici, koja okuplja veliki broj mladih muslimanki i muslimana, ali i kao tajnik jednog od najuspješnijih Odbora za međureligijsku suradnju u našoj zemlji, mogu s punom odgovornošću izraziti svoje zadovoljstvo dosadašnjom suradnjom na projektu Koračajmo zajedno. Posebno se želim osvrnuti na osjetljivost svih projekata koji okupljaju ljude različitih religijskih identiteta, to znači da se nužno mora paziti na osjećaje svih sudionika, njihovu tradiciju, vjerska ubjeđenja i nikada ne dozvoliti se bilo čime dovedu u pitanje vrijednosti koje donose sa sobom. Posebno je osjetljivost bavljanja ovim temama izražena u našem bosanskohercegovačkom društvu, koje je još uvijek mnogo opterećeno traumatičnom prošlošću, iz koje se, i naše crkve i vjerske zajednice nisu do kraja izvukle te pronašle najbolje modele suočavanja sa samima sobom, a onda i s drugima. Mladi ljudi okupljeni u NCM Ivan Pavao II. su, siguran sam, na najbolji način razumjeli ovu našu zbilju i stoga je projekt Koračajmo zajedno ovako uspješan. Nadamo se da će se projekat širiti na svaki grad, svaki džemat/ župu/parohiju, jer kao vjernici bit ćemo odgovorni za naš (ne)angažman u širenju Selama-Mira, među svim ljudima.«

Kenan Hodžić, Zenica

\section{Zaključne misli}

Od početka djelovanja Nadbiskupijskoga centra za pastoral mladih Ivan Pavao II. župnici su djelatnicima i volonterima bili prvi suradnici, a s vremenom smo počeli uključivati sve više i vjeroučitelje iz škola, časne sestre aktivne u pastoralu župnih zajednica, nastavnike i profesore $u$ školama. Zajednički nastojimo hoditi za dobrobit djece i mladih. Sve radi pomlađivanja župnih zajednica. 
Najnoviji pastoralni projekt, pod nazivom Servant leaders for the vital church comunities (Služeći voditelji za dinamične župne zajednice), koji skraćeno zovemo Revitalizacija župnih zajednica, podrazumijeva duhovne obnove i seminare iskustvenoga učenja za bogoslove, časne sestre u pastoralu, vjeroučitelje, vijećnike Vijeća za mlade (predstavnici dekanata i različitih udruga), aktivne župne pastoralne vijećnike zajedno sa svojim župnicima za pastoral djece - osnivanja skauta - uključivanje i roditelja u rad s djecom i mladima u župi. Svi zajedno hodeći možemo doprinijeti životnosti naših župnih zajednica! Svi sudionici upoznaju se s različitim inicijativama u pastoralu djece i mladih u župnim zajednicama, prijedlozima i inicijativama iz Centra - a sve radi revitalizacije župa!

To je ono što želimo postići kada govorimo o sinodalnom pastoralu mladih, riječima pape Franje: »Nošeni tim duhom moći ćemo kročiti prema sudioničkoj i suodgovornoj Crkvi koja je sposobna prepoznati vrijednost svojega bogatstva različitosti, zahvalno prihvaćajući također doprinose vjernika laika, uključujući doprinos mladih $(\ldots) . \ll^{33}$

${ }^{33}$ ChV, br. 206. 


\title{
SYNODAL PASTORAL CARE OF YOUNG PEOPLE - EXPERIENCE IN THE ARCHDIOCESE OF VRHBOSNA
}

\author{
Šimo MARŠIĆ ${ }^{*}$ - Antonio TOPALOVIĆ ${ }^{* *}-$ Marija PULJIĆ $* * *$
}

Summary: Synodality as a style of pastoral work in today's time and understanding of the Church is a significant theological-pastoral theme. Here it will be discussed in the context of youth pastoral care and specifically in the context of the work and activities of the Archdiocesan Center for Youth Pastoral $\gg J o h n$ Paul II $\ll$ in Sarajevo (hereinafter: AYC John Paul II). We will first briefly deal with the notion of synodal pastoral care and the synodal pastoral care of young people as a demand of the present moment. We will then present the vision and mission of the AYC John Paul II, which, through the institution of the Youth Council, promotes synodality, i.e., the involvement of young people in the process of joint decision making in youth pastoral care. Finally, we will focus on three different pastoral projects of the AYC John Paul II, which reveal the synodality in youth pastoral care, on three levels: the formation of animators of parish youth pastoral care, the social engagement of young people through volunteering, and concrete action of young people in interreligious and ecumenical contexts.

Keywords: Synodal pastoral care, Archdiocesan Center for Youth Pastoral $\gg J o h n$ Paul $I I \ll$, Youth Council, youth pastoral, animator, volunteering.

* Assoc. Prof. Šimo Maršić, Ph.D., Catholic Faculty of Theology, University of Sarajevo, Josipa Stadlera 5, 71000 Sarajevo, Bosnia and Herzegovina, marsicsimo@gmail.com

** Antonio Topalović, MSc in Pedagogy, Archdiocesan Center for Youth Pastoral »John Paul II «, Gatačka 18, 71000 Sarajevo, Bosnia and Herzegovina, antonio_topalovic@hotmail.com

*** Marija Puljić, MSc in Geography, Archdiocesan Center for Youth Pastoral »John Paul II «, Gatačka 18, 71000 Sarajevo, Bosnia and Herzegovina, marija.ncm@gmail.com 